Ola Magntorn is a senior lecturer in science education at Kristianstad University. He has long experience of teaching in schools at different levels as well as in teacher education. His main focus of research is on the development of

\title{
Minnesvärda episoder i undervisningen- en studie av elevers episodiska minnen från en undervisningssekvens i biologi
}

\begin{abstract}
This study explores primary school students' abilities to recall events from a teaching sequence taking place 18 months earlier. The aim of the teaching sequence was to develop students' ability to read nature in a river habitat. The concept reading nature has to do with an ability to recognise organisms and relate them to material cycling and energy flow in the specific habitat which is to be read. In this study the aim is to analyse the episodes the students recall in order to find patterns in students' views of memorable learning events. Combining the affective and cognitive domains by first hand experiences which challenge students' everyday conceptions and to involve them in the design of the activities make lasting impressions in the long term memories of the majority of students. These memorable episodes can be useful to relate to in the further classroom teaching about the content knowledge of science in order to make it more meaningful for the students.
\end{abstract}

\section{INLEDNING}

Kan du minnas ett undervisningstillfälle du varit med om eller en lärandesituation som skett för flera månader eller till och med år sedan? Inte sällan minns vi specifika tillfällen eller händelser som på ett eller annat sätt berört oss. Med episodiskt minne menas långtidsminnet av särskilda personliga händelser i form av detaljer (vad) platsen där det hände (var) eller vid vilket tillfälle det skedde (när). Denna typ av minne har oftast en unik lärandesituation kopplat till sig. Kontexten är alltså viktig. Det kan ses som en specialiserad form av vårt generella minne där episodiskt minne skiljer sig genom att det kräver tillgång till kontexten och personligt deltagande i en händelse som betraktas som en minnesvärd episod (Buckner \& Barch, 1999). Dessa episodiska minnen är ofta väldefinierade händelser som "etsat sig fast i minnet" och som inte sällan kan uttryckas med stor exakthet fastän flera år passerat sedan de inträffade (White \& Gunstone, 1992). En av de viktiga karaktärerna hos det episodiska minnet är att de tillăter oss att "resa bakåt i tiden". Det innebär att en person som minns en tidigare episod kan mentalt associera till och erfara de känslor eller andra intryck som upplevdes vid denna tidigare händelse (Tulving, 2002). 
Ett exempel på en sådan episod är när Anders i Gustav Helldéns longitudinella studie om barns tankar om ekologiska processer, år efter år återkommer i intervjuerna om nerbrytning till en episod om komposten och hur det blir jord av de köksavfall som läggs i komposten. Ett minne som Anders burit med sig sedan han var liten och blev förevisad komposten av sin granne (Helldén \& Solomon, 2004). Vi bär alla med oss minnen från händelser och gemensamma minnen kan vara värdefulla utgångspunkter för undervisningen. Lärande är en mycket komplex process där bland annat våra tidigare erfarenheter påverkar vårt sätt att tolka nya upplevelser eller beskrivningar av verkligheten. Detta innebär att en klass som är med om samma händelse i naturen, t.ex. en sländlarv som kläcks och flyger iväg som slända, har lika många individuella upplevelser av detta som det är elever i klassen. Psykometrisk forskning visar att när en händelse som den med komposten skall återberättas och det episodiska minnet aktiveras så berörs en större mängd centra i hjärnbarken på ett sätt som tyder på att denna minnesfunktion är både personligt färgad och dessutom hos varje individ starkt komplex (Buckner \& Barch, 1999; Dere, Kart-Teke, Huston \& De Souza Silva, 2006).En utgångspunkt vid designen av den undervisningssekvens eleverna deltar i är att den skall erbjuda aktiviteter som kan skapa episodiska minnen och att dessa kan stärka det semantiska minnet d.v.s förståelsen kring ett fenomen genom att eleven kopplar episodiska minnen till ämnesteori. Dessa långtidsminnen av händelser har Gagné och White (1978) studerat hos elever och studenter och de menar att långtidsminnet omfattar fyra kunskapsinslag, nämligen verbal kunskap, intellektuell färdighet, inre bilder och episoder. Dessa episoder är minnesbilder av aktiviteter som individen deltagit i. De hävdar att förmågan att minnas något beror på hur väl händelsen kan länkas i minnet till andra erfarenheter såsom specifika situationer. De menar också att något man lärt sig nyligen, såsom verbal kunskap eller intellektuell färdighet, kommer att bevaras längre i minnet om det kan kopplas till episoder som är minnesvärda. Det lärande som skett i en situation förutsätts kunna appliceras i en annan situation eller knytas an till långt senare på ett meningsfullt sätt för eleven. Detta grundantagande bygger på att kontexten är viktig men också på att den lärande bär med sig kunskaper från tidigare situationer och kan återknyta till dessa.

\section{OM ATt LÄSA NATUREN}

Förmågan att Läsa Naturen är centralt i detta arbete och behöver förklaras helt kort. Det skall ses som en viktig aspekt av ekologisk allmänbildning som i grunden har att göra med att utveckla ett förhållningssätt till naturen som är långsiktigt hållbart och som bygger på kunskap om naturen och människan i naturen (Orr, 1992). Begreppet Läsa Naturen fokuserar på ekologi och på utomhusmiljön. Det har att göra med att känna igen organismerna i deras vanliga livsmiljö och kunna relatera dem till kretsloppen och till energiflödet i ekosystemet som skall läsas. De redskap vi har är våra erfarenheter från lärandesituationer både utomhus men också från undervisning $\mathrm{i}$ klassrummet. I detta fall är naturen begränsad till ett vattendrag med dess organismer.

Studien fokuserar på vad elever minns av en undervisningssekvens som skett 18 månader före intervjutillfället och om det finns några kvalitativt gemensamma drag i de episoder som eleverna refererar till. Studien är den tredje i en sekvens som handlar om grundskoleelevers förmåga att Läsa Naturen. Eleverna i årskurs 3-4 (9-11 åringar) studerade under en termin ett vattendrag strax intill skolan. I en tidigare artikel har elevernas förmåga att Läsa Naturen studerats i relation till undervisningssekvensen beskrivits (Magntorn \& Helldén, 2006). I denna studie fokuseras intresset på vad eleverna refererar till för händelser eller episoder från undervisningssekvensen. Tidigare studier betonar vikten av direkta möten och förstahandsupplevelser ute i naturen. I en stor internationell genomgång av didaktisk forskningen kopplat till utomhusundervisning och fältstudier skriver Rickinson et al, (2004) att:

"fieldwork can have a positive impact on long term memory, due to the memorable nature of the fieldwork setting and there can be reinforcement between the affective and the cognitive, with each informing the other and providing a bridge to higher order learning". 
Förutom förståelsen för hur naturen fungerar påverkas också elevernas attityd till naturen. Chawla (1998) betonar också vikten av att undervisningen ger eleverna positiva erfarenheter och upplevelser av naturen som de senare kan återknyta till och som kommer att kunna påverka deras framtida förhållande till naturen. Hon kallar dessa för "significant life experiences" och beskriver hur det vid metakognitiva intervjuer om orsakerna till att en person har en viss övertygelse kring miljö eller natur, ofta framkommer att det bottnar i tidigare upplevelser eller episoder som präglat denna inställning. Novak betonar också att det är såväl tänkandet men också i stor utsträckning känslor och aktiviteter som är avgörande för att utveckla förståelse för naturen (Novak, 1998).

\section{OM LÄRANDE OCH DESIGNEN AV UNDERVISNINGSSEKVENSEN}

Den bakomliggande epistemologiska uppfattningen är teorin om meningsfullt lärande (Ausubel, 1968) som kompletterats med Novak's Human constructivism som understryker betydelsen av kombinationen av känslor, personlig relevans och kontext vid lärande. Den som lär sig utvecklar ständigt sina begrepp i relation till sin omgivning (Novak, 1998). Vid meningsfullt lärande blir relationen mellan det man redan vet och det nya man upplever bättre utvecklad och begreppen blir bättre integrerade med den tidigare kunskap man har. Meningsfullt lärande förutsätter att eleven vill lära sig och att det som eleven skall lära sig känns relevant. En ytterligare aspekt på förutsättningar för lärande som inte Ausubel och Novak nämner men som bland annat Wickman (2006) ser som en viktig förutsättning för lärande är de estetiska aspekterna kopplat till lärandesituationen. Han skriver om positiva och negativa estetiska aspekter som i båda fallen kan skapa minnesvärda episoder oavsett om man tilltalas eller avskräcks av de upplevelser man fått eller av de organismer man sett. Den affektiva dimensionen för lärande d.v.s. att eleven tycker det är något som berör och därmed känns meningsfullt bör betonas extra och har bland annat beskrivits av Watts och Alsop (1997) som menar att det som skall läras måste sticka ut eller vara avvikande från det man är van att se. Det måste vara begripligt för eleven och relevant utifrån elevens tidigare erfarenheter. Kopplingen mellan affektiva och kognitiva aspekter på lärande i biologi och hållbar utveckling lyfter också Littledyke (2008) fram och menar att naturvetenskapen och i synnerhet ekologin bör länkas tydligare till hållbar utveckling och miljöfrågorna och mer diskutera affektiva värden. Även historier och personliga anekdoter kopplade till det naturvetenskapliga innehållet har stor betydelse för lärandet och utgör en del av kunskapen och bildningen i naturvetenskap (Klein, 2006).

Hur ser då dessa aktiviteter ut som får eleverna engagerade och som får dem att minnas händelser år efter år och finns det gemensamma drag i vissa aktiviteter som flera elever minns? Grundläggande för designen av själva undervisningen har bland annat en fenomenologisk studie av Knapp och Benton (2006) varit. De har intervjuat femteklassare om vad de minns av en exkursion som gjordes ett år tidigare. De visade på tre förutsättningar som krävdes för att eleverna skulle redogöra för händelsen som en episod och för att de skulle koppla denna episod till ett meningsfullt ämnesinnehåll (semantisk förståelse) Dessa tre var 1) repetition av händelser eller begrepp, 2) informationen gjordes relevant för eleven, 3) eleverna gavs förstahands erfarenheter genom praktiska övningar. I den sammanfattning av undervisningssekvensen som finns längre fram i artikeln beskrivs ämnesinnehållet men det som inte framgår där är att pedagogen också genomgående är mån om att erbjuda eleverna dessa tre förutsättningar.

\section{SYFTE OCH FORSKNINGSFRÅGOR}

Syftet med denna studie är att undersöka vilka aktiviteter som eleverna minns från undervisningssekvensen och genom att be dem reflektera om varför de minns dessa aktiviteter också kunna identifiera olika episoder och försöka karakterisera dessa och hur de kopplas till ämnesinnehållet. Implikationer för undervisningen kommer också att diskuteras. 
Forskningsfrågorna är.

- Vilken typ av aktiviteter refererar eleverna till från undervisningssekvensen?

- Vilka gemensamma drag i dessa minnesvärda aktiviteter kan urskiljas?

- Vilken typ av episoder förknippar eleverna med minnesvärda aktiviteter

- Finns det ett samband mellan vilka aktiviteter eleverna minns och deras förmåga att läsa naturen efter avslutad undervisning?

\section{UNDERVISNINGSSEKVENSEN}

Hela undervisningssekvensen bestod av 7 undervisningstillfällen av varierande längd mellan 80 och 200 minuter. Dessa lektioner innehöll både utomhus och klassrumsaktiviteter.

Av utrymmesskäl kommer undervisningssekvensen att beskrivas helt kortfattat men för att ge ökad transparens och för den som är intresserad av att få en bättre bild av aktiviteterna finns en 40 minuter lång film som redogör för undervisningens alla sekvenser.

mms://194.47.25.160/mna/vramsafilmen.wmv Undervisningen kan beskrivas i fyra delar som bygger på varandra och som startar i en organism, sötvattensmärlan (Gammarus pulex). Sedan vidgas perspektivet till att slutligen studera ekosystemet på en systemnivå där fortfarande sötvattensmärlan är central. Detta har benämnts ett botten-upp perspektiv (se figur 1). För att kunna relatera till det eleverna minns följer här en kortfattad beskrivning av de genomförda undervisningsmomenten (se tabell 1). Inledningsvis introducerades sötvattensmärlan och eleverna fick håva in den och ställa produktiva frågor om den som de sedan fick söka svar på genom att studera djuret. Vid det första tillfället tränades framför allt observationsförmågan och morfologin och beteendet hos märlan studerades. I del två vidgades perspektivet och eleverna fick studera andra djur och upptäcka hur de är anpassade till ett liv i strömmande vatten. De studerade djur och växter i forsande och i lugna partierna av ån och jämförde dessa. De provade på att håva och samla in djur på olika sätt. De gjorde ett fältförsök som gick ut på att testa vad märlorna åt. Små nätpåsar, ungefär som grovmaskiga tepåsar, med märlor och olika sorters föda sattes ner i det rinnande vattnet under en veckas tid för att sedan tas upp och studeras. I del tre diskuterades vad djur och växter behöver för att leva och eleverna fick lära sig skilja på rovdjur, växtätare och nerbrytare. Som avslutning på denna lektion fick de titta på djuren i mikroskop. De gjorde sedan ett försök som vi kallade "Vramsån på burk" där eleverna i små grupper fick bestämma hur de skulle kunna bygga ett slutet ekosystem i miniatyr där organismerna kunde leva en längre tid trots att locket var stängt och inget gasutbyte med omgivningen kunde ske. Dessa burkar studerades sedan en gång i veckan och i slutet av projektet öppnades burkarna igen och eleverna fick diskutera kretslopp och vad som hänt med luft och mat i burken. De byggde en näringsväv av ett gammalt fiskenät där bilder på djuren klistrades in efter deras funktion i näringsväven. Livscykler diskuterades eftersom flera av insektlarverna som stoppades i burken kläcktes till färdiga insekter och nya djur dök upp från ägg som av misstag kommit i burken. Eleverna lekte också en lek där de tillsammans fick agera olika djur från ån och där de skulle vara strategiska så att de själva fick tillräckligt med mat men inte blev uppätna. I del fyra, vid det sista besöket vid ån, gjordes en enkel miljötest av ån där vattenkvalitet bestämdes utifrån enkla parametrar såsom vilka känsliga djur som fanns, hur forsande vattnet var och hur omgivningen ser ut. Avslutningsvis illustrerades fotosyntesen och växternas förmåga att bygga socker med hjälp av solljus och luft och vatten där olikfärgade legobitar representerade de olika grundämnena syre, väte och kol. Målet var att eleverna skulle få en uppfattning om materia och att växterna mest lever av luft (koldioxid) och vatten. Klorofyllkockar var en metafor som användes om processen där "kockarna" lagar socker av "luft" och vatten med solljuset som energikälla till spisen. 


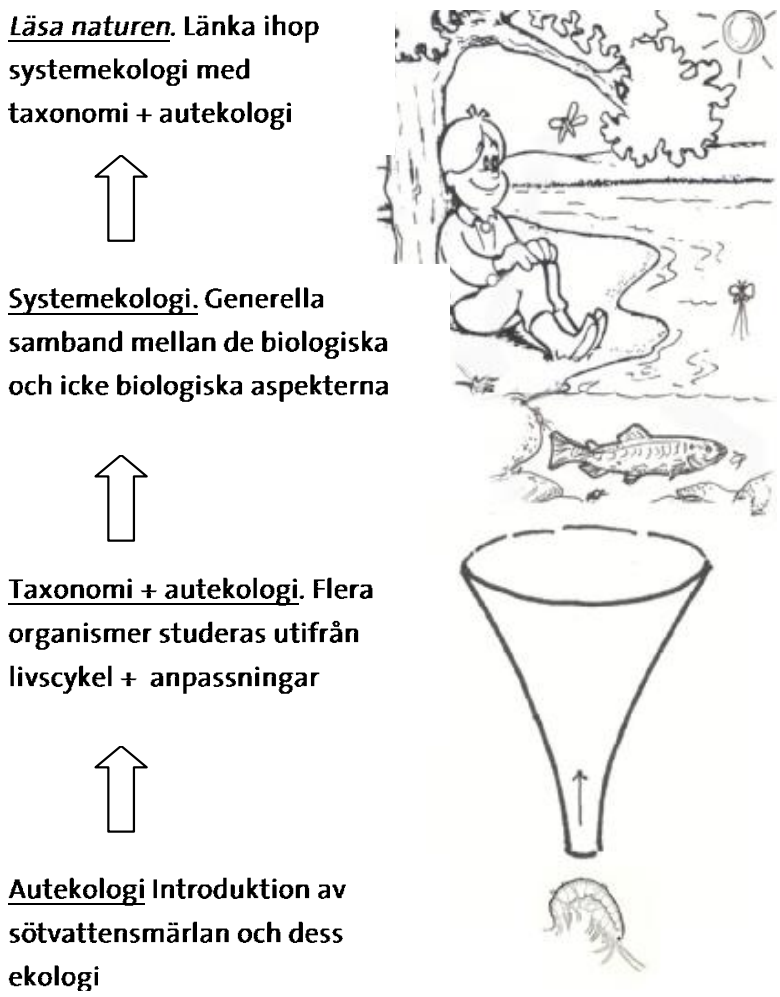

Figur 1. Bilden visar "botten-upp perspektivet" där aktiviteterna startar i studien av märlan och vidgas sedan mot hela ekosystemet.

\section{METOD}

Tio av de 22 eleverna gjorde en uppföljande intervju 18 månader efter undervisningen. Dessa tio var inte slumpvis utvalda utan valdes för att representera den spridning i förmågan att Läsa Naturen som fanns i klassen. Detta är baserat på intervjuer som gjorts direkt efter avslutad undervisning då eleverna delades in i tre grupper baserat på deras förmåga att länka artkunskap och arternas ekologi i ekosystemet till mer abstrakta processer såsom kretslopp på systemnivå. Tre elever från den grupp som klassades högst (nivå 1), fyra elever från mellangruppen (nivå 2) och tre elever från gruppen med lägst förmåga. (nivå 3). För noggrannare uppgifter om elevernas nivå se Magntorn \& Helldén,( 2006). Det främsta skälet till detta urval är att utifrån den goda kunskap som finns om varje elevs förmåga att Läsa Naturen kunna göra ett urval som väl representerar hela klassen. Denna gradering ger också möjlighet att urskilja om det finns en tydlig koppling mellan vad eleverna relaterar till och deras förmåga att Läsa Naturen efter avslutad undervisning.

Den inledande intervjufrågan löd "Kan du berätta för mig vad du kommer ihåg av det ni gjorde när ni undersökte ån förra året"? Denna fråga är formulerad för att belysa vilka aktiviteter som eleven kommer ihåg utifrån den undervisningssekvens som beskrivits tidigare i artikeln. I samband med denna fråga fick eleverna enbart tillgång till ett fotografi över ån vid den plats där studien genomförts 18 månader tidigare. Frågan följdes sedan upp med en fråga av metakognitiv karaktär som löd: Hur kommer det sig att du minns just detta? Utgångspunkten är att närvaron av forskaren (som passivt deltagit vid undervisningen) tillsammans med bilden av ån hjälper eleverna att minnas olika episoder från undervisningen. Detta kan betraktas som en typ av stimulated recall 
intervju. Den bakomliggande idén med stimulated recall är att den intervjuade skall kunna återuppliva minnen från en tidigare autentisk situation och med stor livfullhet och säkerhet återge detta om han presenteras med ett antal stimuli eller objekt som hör till den ursprungliga situationen när händelsen utspelades (Haglund, 2003)

Metodologiskt kan denna typ av semistrukturerade intervjuer ge en god bild av elevens uppfattningar om olika fenomen eller företeelser i naturen (Duit, Treagust \& Mansfield, 1996). Intervjudesignen ger också möjlighet till viss flexibilitet, där intervjuaren kan följa upp vissa teman som kan dyka upp under intervjun. Vid en pilotstudie med några elever var frågorna helt öppet ställda och eleverna ombads berätta om allt de minns från när de undersökte ån. Denna typ av intervjuer gav ett väldigt rikt dataunderlag och eleverna refererade ofta till moment som inte hade med det naturvetenskapliga innehållet att göra utan var mer av personlig eller social karaktär. Detta är intressant men utanför fokus i denna studie som fokuserar på aktiviteter de minns och hur de förknippas med episoder och eventuellt hur detta relaterar till förmågan att Läsa Naturen. Data samlades in genom individuella semistrukturerade intervjuer som fick eleverna att fokusera på det naturvetenskapliga innehållet. Vid analysen av intervjuerna har varje elevsvar analyserats för sig utifrån de teman eller mönster som framkommit. Samtliga intervjuer har transkriberats och kategoriindelats utifrån vad varje elev nämnt och i vilken ordning aktiviteterna beskrivits. Vid analysen av de metakognitiva frågorna har lyft fram gemensamma drag hos de aktiviteter som nämns och som eleverna kopplar till episoder. Denna typ av svar ger ett rikt underlag där olika aspekter framträder t.ex. när elever, oberoende av varandras svar, ger snarlika förklaringar till varför de minns en viss händelse. Det har inte varit möjligt att redovisa alla svar. Ett urval av representativa svar eller anekdoter från intervjuerna har fungerat som en form av validering av data, vilket förekommit i liknande studier e.g. Clark's historical narratology (Clark, 1995).

\section{RESULTAT OCH ANALYS}

Intervjuernas varade ca 30 minuter och under denna tidsrymd hinner eleven nämna många och skiftande aktiviteter och episoder. Vid urvalet av aktiviteter och episoder som har betraktats som relevanta har endast räknats sådant som direkt berör det naturvetenskapliga ämnesinnehållet och som är relaterat till att Läsa Naturen. Dessa aktiviteter finns beskrivna i undervisningssekvensen ovan. Semantiska uttalanden såväl som affektiva eller estetiska med bäring på undervisningen eller upplevelser av naturen har varit de som ingått i själva analysen. Att dra gränsen mellan det som är relevant är långt ifrån enkelt och urvalet har diskuterats med flera forskarkollegor.

\section{Aktiviteterna}

Vid analysen av den första frågan, som var helt öppen och behandlade vad eleverna mindes, framträder en tydlig bild där vissa aktiviteter nämns av alla, eller nästan alla och några aktiviteter nämns bara av enstaka elever. Som framgår av tabell nr 1 refererade alla eleverna till det slutna ekosystemet "Vramsån på burk". Denna aktivitet innebar att eleverna åter fick bekanta sig med organismerna $i$ ån. Kunskapen om djuren gjordes relevant eftersom de själva skulle välja vad som skulle ingå i burken och de fick förstahandsupplevelser genom att aktivt bestämma burkens innehåll. De fick dessutom en gång i veckan studera burken. Då togs burkarna in från ett förråd där den befann sig eftersom det varit för varmt att ha dem i klassrummet. Alla tre kriterierna för att skapa episodiska minnen som Benton och Knapp (2006), refererat till är således representerade. Nedan följer ett urval av aktiviteter som de flesta eleverna nämnde. De episoder som eleverna nämner har lite olika karaktär och de har delats in i tre typer. Den vanligaste är den affektiva/estetiska som har att göra med syn- och luktupplevelser eller känslor som väcks när de studerar något. Den andra typen av episod kan beskrivas som "utmanande" och har att göra med att deras ontologiska uppfattningar blir utmanade. En tredje episod är "bekräftande" och syftar på att eleven upplever att den hade rätt i sitt antagande. Denna episod förekommer när eleverna haft hypoteser om något fenomen som sedan visat sig vara korrekt. 


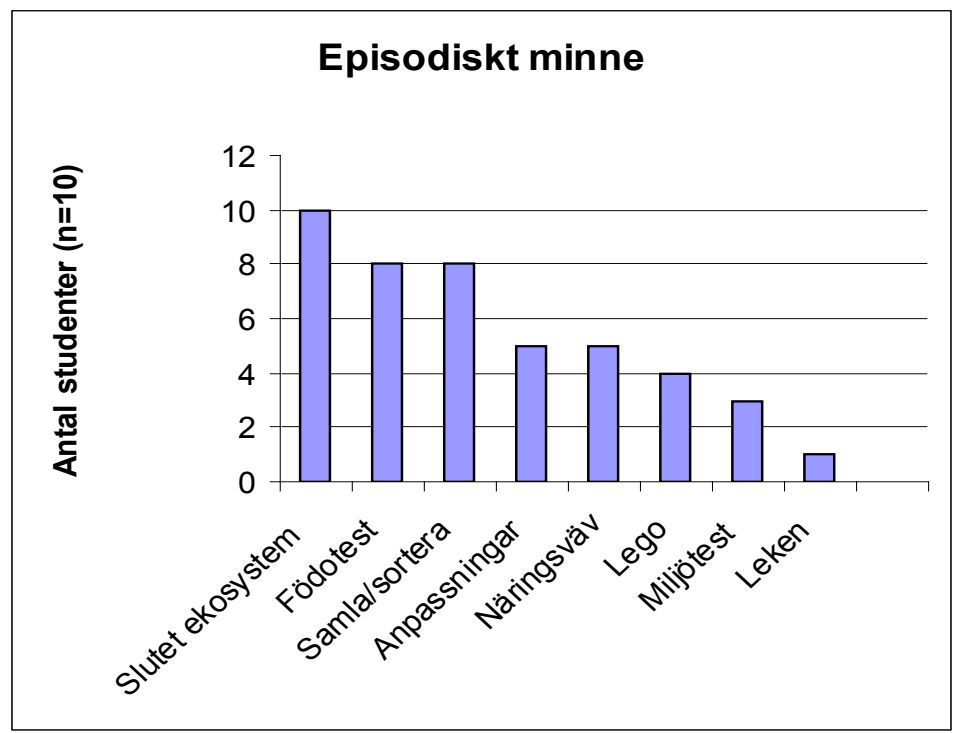

Figur 2. Stapeldiagram över vad eleverna minns för episoder 18 månader efter undervisningen

Tabell 1. De aktiviteter eleverna nämnde och i vilken ordning de nämndes.

I tabellen anges vilka elever som nämnde de olika aktiviteterna och $i$ vilken ordning dessa nämndes (1-6). Varje elev anges också med en siffra från 1-3 som refererar till förmågan att Läsa Naturen där siffran 1 indikerar högsta förmåga.

\begin{tabular}{|l|l|l|l|l|l|l|l|l|}
\hline $\begin{array}{l}\text { Elev + kun- } \\
\text { skapsnivå 1-3 }\end{array}$ & $\begin{array}{l}\text { Slutet } \\
\text { Eko- } \\
\text { system }\end{array}$ & $\begin{array}{l}\text { Födo- } \\
\text { test }\end{array}$ & $\begin{array}{l}\text { Anpassning } \\
\text { Lugn / For- } \\
\text { sande å. }\end{array}$ & $\begin{array}{l}\text { Närings- } \\
\text { väv }\end{array}$ & $\begin{array}{l}\text { Håva/ } \\
\text { sortera }\end{array}$ & $\begin{array}{l}\text { Miljö- } \\
\text { test }\end{array}$ & Lego & Leken \\
\hline Anna (1) & 1 & 2 & 3 & - & 4 & - & 5 & - \\
\hline Eva (1) & 1 & 2 & - & 3 & 4 & - & - & - \\
\hline Kristin (1) & 6 & 4 & 3 & 2 & 5 & 1 & - & - \\
\hline Karl (2) & 2 & 3 & - & - & 1 & 4 & 5 & - \\
\hline Peter (2) & 3 & - & 4 & - & 1 & 2 & - & - \\
\hline Adam (2) & 2 & 3 & - & 4 & 1 & - & 5 & - \\
\hline Josefin (2) & 1 & - & - & - & 2 & - & 3 & 4 \\
\hline Kristian (3) & 1 & 2 & 5 & 4 & 3 & - & - & - \\
\hline Johan (3) & 1 & 3 & 2 & - & 4 & - & - & - \\
\hline Susann (3) & 1 & 2 & - & 3 & 4 & - & - & - \\
\hline
\end{tabular}




\section{Vramsån på burk}

Samtliga elever nämner att de byggde slutna ekosystem. På följdfrågan om varför de kommer ihåg just denna episod ger sju av dem ett svar som tolkas som att uppgiften har utmanat deras föreställning om kretslopp och hur ekosystemet kan fungera där just stängningen av locket på burken är den episod som nämns av flera. Majoriteten minns också vad de stoppade i sin burk och vad som hände med alla djuren. Dessa två episoder kan kopplas till att de haft inflytande över aktiviteten och att de varit motiverade att följa vad som skulle hända med just deras burk. Det som hände utmanade elevernas föreställningar och denna aspekt på episoder benämnes "utmanande". De flesta nämner också aspekter som kan kallas estetiska eller affektiva och har att göra med syn- eller luktupplevelser. Några exempel på citat från eleverna i anslutning till de olika aktiviteterna är beskrivna nedan. Dessa citat kompletteras med episodens karaktär.

Anna har förklarat att hon minns att de byggde det slutna ekosystemet

Intervjuaren: Hur kommer det sig att du kommer ihåg just det?

Anna: Vi byggde ju den där Vramsån på burk. Jo, det var kul men lite läskigt (affektiv aspekt). Intervjuare: Hur då läskigt, menar du?

Anna: Ja, eeeh, att vi skulle stänga in alla djuren med locket på. Men det funkade inte så bra i vår burk.(utmanande aspekt)

Intervjuare: Näha, varför då?

Anna: Ja, syret tog slut för det var bakterier som tog slut på det och då dog allt annat och det luktade jätteäckligt (affektiv aspekt). Vi fick tömma ut den på skolgården i ett avlopp. (hon grimaserar) (affektiv aspekt)

Peter nämnde också det slutna ekosystemet och beskrev det så här:

Peter: Burken hade vi i fyra veckor. Det var köttätare och växtätare, växter och jord och så.

Intervjuaren: mmm, hur kommer det sig att du minns det där med burken?

Peter: Ja, eeh, det var bara rovdjur kvar för de hade ätit upp alla växtätarna. En grupp hade totaldött, liksom och andra hade allt kvar. Det var lite konstigt att de kunde leva i burken. (utmanande aspekt)

Karl förklarade att han blev förvånad att djuren kunde leva så länge i burken med locket på.

Karl: Vi håvade och hade djur i burk och skruvade på locket för att de inte skulle smita. Sen hade vi den i fyra veckor och, ja, eeh, till sist blev det utan syre och luktade skit, men det dröjde länge minns jag (affektiv + utmanande aspekt)

Dessa tre exempel på uttalanden tolkas som att momentet med att stänga burken och inte släppa in ny luft utmanade deras vardagsföreställningar och bidrog till att de minns händelsen.

\section{Håvningen}

Åtta av eleverna nämner att de håvade och samlade in djur i vattnet. Detta var en aktivitet som eleverna gjorde vid tre olika tillfällen och det första tillfället var för de flesta eleverna den första kontakten med smådjur i rinnande vatten. Aktiviteten gick i huvudsak ut på att hitta så många olika livsformer som möjligt i vattnet och hur och var de letade var inte i förväg definierat. På frågan om varför de minns just detta gav sex av eleverna uttryck för att det var spännande, kul, eller häftigt att håva i ån. Dessa affektiva aspekter tycktes viktiga. De nämnde också att de hittade många olika djur och att de själva fick leta efter djuren på olika ställen. Fyra elever gav uttryck för en fascination över alla livsformer i vattnet. Två av dessa var Karl och Adam. 
Karl: Det fanns så många häftiga djur under vattnet. Såna husmaskar (Trichoptera), Dom var mina favoritdjur. Det var kul att håva (affektiva aspekter)

Adam: Under de stora stenarna kryllade det av iglar. Dem var svåra att fånga. Dem rörde sig så konstigt.(affektiv + utmanande aspekt)

Upprepning av aktiviteten och möjligheten att på egen hand eller i grupp få undersöka ett okänt ekosystem tolkas som viktiga orsaker till att de minns håvningen och det som antas hjälpa dem att minnas aktiviteten är just det stora antal djur som de hittade och som de flesta nämner. Artkunskapen i sig bör betraktas som semantisk kunskap men oavsett hur den skall tolkas tycks organismerna som de så ofta nämner, ha en stor påverkan på deras förmåga att minnas och associera till aktiviteterna.

\section{Födopreferens}

Åtta av eleverna nämnde födopreferensförsöket med nätpåsarna där märlorna och maten var instängd. Även detta försök hade karaktären av att eleverna fick vara med och aktivt ställa hypoteser om vad som skulle hända och vad märlorna skulle äta? De fick också inflytande över var påsen placerades i ån, men materialet och metoden var given från början.

Anna: Jag minns att dom bara åt de gamla löven, inte de gröna precis som vi trodde. (bekräftande aspekt).

Peter: Ja de åt bara det mörka, dem gamla löven. (bekräftande aspekt).

Johan: Det var något med pinnar och påsar eeh ja vår påse gick sönder och allt var förstört. (affektiv aspekt)

Dessa citat visar på betydelsen av att "få ha rätt" d.v.s en bekräftande aspekt som betraktas som ett episodiskt minne byggt på en känsla av att kunna något. En annan känsla som också ger episodiskt minne är det misslyckande Johan redogör för. Händelser som kan betraktas som negativa eller besvikelser skapar också episodiska minnen (Knapp \& Benton, 2006) men de var inte vanliga i denna studie.

\section{Lugnt och forsande vatten}

Fem elever nämner hur de studerade djurs anpassningar till lugnt och forsande vatten och alla nämner i det sammanhanget några olika djur som trivs i forsande vatten. De organismer de hittade vid de olika delarna av ån gav episodiska minnen, i synnerhet av mer spektakulära djur såsom husmasken.

Peter: Jag kommer ihåg när vi håvade de där husmaskarna. Det var skillnad på dem. (affektiv aspekt). De byggde ju hus av småstenar i forsen, annars skulle de ju flyta med i forsen"

Kristin: Alla håvade liksom på olika ställen eeh, och vi var mest i fallet där det slingrar sig. Där fanns massor med märlor och iglar och ja, såna husmaskar som var gjorda av sten. Dem var kul (affektiv aspekt)

\section{Näringsväven}

Näringsväven som klassen byggde och diskuterade nämndes också av fem elever. I detta fall refererade eleverna till att de tyckte det var roligt att rita fina bilder av djuren och att nätet med djuren blev snyggt. Det handlar alltså till stor del om en estetisk aspekt på den minnesvärda episoden. Själva metaforen med väven som ett sätt att illustrera ekosystemet nämndes endast av Anna och Peter. 
Tre elever nämner också att de gjort något med LEGO-bitar men de minns inte riktigt vad det var. Alla tre nämner att det handlade om syre och något som hette koldioxid men på en följdfråga är det enbart en elev (Anna) som minns att växterna gjorde syre och att djuren behövde andas detta syre. Det som alla tre refererar till är ordet "klorofyllkockar" som läraren använde som metafor för hur sockret bildas vid fotosyntesen av små "klorofyllkockar" i bladen. Själva processen kunde ingen redogöra för på ett korrekt sätt.

\section{Övriga aktiviteter}

Endast en elev nämner leken där de själva fick agera olika djur i ån och utsättas för att vara jagade eller jaga andra och sedan diskutera näringsväven i ån. På frågan om varför hon mindes det svarar hon:

Josefin: Jag minns nog eeeh för jag fick vara rovdjur i den där leken.(affektiv aspekt)

Mikroskoperingen som kunde förväntas varit en ny och spännande aktivitet nämndes endast av en elev (Johan) och den episod han nämner är att: "det var så häftigt att se vad de hade ätit till frukost" (eftersom vissa djur var genomskinliga syntes detta i mikroskopet).

Tre elever nämner miljötesten som gick ut på att försöka klassa åns naturvärden. Endast Kristin nämner en episod i anslutning till detta och det är att de mätte vattenhastigheten med hjälp av hur snabbt ett äpple flöt fram $\mathrm{i}$ ån och att hög vattenhastighet var bra. Alla tre nämnde att ån var frisk. Övriga aktiviteter som nämndes kort av enstaka elever och där de saknade en fördjupande beskrivning av hur det gick till eller varför de gjorde det har inte tagits med i protokollet trots att eleverna bar på många individuella och ofta fragmentariska minnen av episoder eller fakta utan förankring i naturvetenskaplig teori eller utan att eleverna kan utveckla hur detta hängde ihop med att Läsa Naturen. Dessa utsagor bedömdes som alltför fragmentariska och osäkra ifråga om tolkningsmöjligheter för att tas med i analysen.

\section{Organismerna}

Alla elever nämnde namnen på olika organismer som de kände till från ån. När de bara nämnde namnen på dem utan att kunna hänvisa till någon episod eller affektiv aspekt bedömdes kunskapen vara av semantisk karaktär. Den organism som samtliga nämnde var sötvattensmärlan och alla nämnde också semantiska minnen om dess ekologi och utseende. Andra organismer som de nämnde och hade affektiva episoder att anknyta till var framför allt sådana som var läskiga eller lite farliga. Bland annat nämnde de flesta av eleverna iglarna och husmaskarna. Tre elever nämnde ryggsimmarna som kunde stickas och som vid något tillfälle började flyga omkring i klassrummet och satte skräck i flera av eleverna.

Vid analysen av vilka aktiviteter eleverna minns i relation till hur väl de kunde Läsa Naturen efter avslutad kurs framgår inget tydligt samband mellan kunskapsnivå och aktiviteter. Elevantalet är alltför litet för att kunna göra en relevant statistisk undersökning men utifrån tabell 1 samt hur de resonerar om vad de minns framträder en tydlig bild av hur vissa aktiviteter genererar episoder hos majoriteten av gruppen och andra aktiviteter inte skapar minnen som återkallar. Det finns en stor samstämmighet kring vissa aktiviteter som skapade episodiska minnen hos alla eller nästan alla elever och dessa episodiska minnen var oftast affektiva oavsett elevernas förmåga att Läsa Naturen. Spridningen var däremot stor kring de aktiviteter som få elever refererade till men även här saknades ett tydligt mönster. Snarare är det en stor spridning i vad de enskilda eleverna minns och hur många aktiviteter de minns.

Vid analysen framkommer några särdrag som kompletterar de förutsättningar som Knapp och Benton (2006) lyft fram. När intervjuerna analyserats och de aktiviteter som eleverna minns har kopplats till ämnesinnehåll och typ av aktivitet, framträder följande särdrag hos de aktiviteter som gett upphov till episoder de minns: 
1. Aktiviteten utmanar elevens vardagsföreställningar eller idéer.

2. Eleverna blir en aktiv del av händelserna med inflytande istället för en passiv åskådare.

3. Eleverna genererar egen information genom förstahandsupplevelser som inte bara är bekräftande utan även tillför nya idéer och kunskaper.

4. Det finns en för eleverna tydlig länk mellan aktiviteten i fält och den uppföljande aktiviteten och diskussionen i klassrummet.

5. Aktiviteterna ger möjligheter för eleverna att uppleva med flera sinnen och skapa affektiva episoder kopplade till ämnesinnehållet.

Vid de första två punkterna finner vi moment som de flesta eleverna refererar till som något av det första de minns. Det slutna ekosystemet nämner alla eleverna. Oavsett hur goda läsare av naturen de var efter undervisningen så fanns här inslag som utmanade elevernas föreställningar om hur biologiska system fungerar. Detta moment innebar också att punkt två berördes eftersom eleverna fick ta ett aktivt inflytande över designen på det slutna ekosystemet. Även punkt tre omfattas av försöket med burken eftersom varje slutet ekosystem var unikt och eleverna fick beskriva och dra slutsatser om sin specifika "Vramså på burk".

Den andra aktiviteten som många av eleverna hänvisar till är försöket med födopreferens. Detta berör framför allt punkterna två, tre och fyra. Försöksdesignen var från början given men resultatet var svårt att förutsäga och försöket presenterades av läraren som ett spännande experiment för att lära sig mer om märlorna. En annan aktivitet som de flesta minns är när de håvade och samlade in organismerna vid flera tillfällen. I detta sammanhang studerades också anpassningar och funktionella grupper såsom rovdjur och växtätare. Det berör framför allt punkterna två, tre och fyra eftersom eleverna inte hade några tydliga förväntningar på vad de skulle finna vid de olika platserna. Händelser eller aktiviteter som inte genererade några episodiska minnen mer än hos ett fåtal elever var t.ex. när de använde legobitar för att bygga molekylerna i fotosyntesen och respirationen och när de lekte ekosystemleken där de själva fick agera något av de djur de stött på i ån. Dessa två moment saknade de tre första punkterna men kan kopplas till punkt fyra då detta återkom i andra former i undervisningen.

\section{Diskussion}

Denna studie syftar till att belysa de minnen elevernas har från en undervisningssekvens och att koppla aktiviteterna till episodiska minnen Resultaten visar att samtliga intervjuade elever minns ett stort antal aktiviteter och de kommer också ihåg namnen på ett stort antal djur. Dessa resultat stämmer väl in med citatet av Rickinson med flera (2004) i inledningen om att utomhusundervisning kan ge upphov till minnesvärda episoder. Inledningsvis diskuterades också tre förutsättningar för att elever i denna ålder skulle skapa episodiska minnen och för att de skulle koppla denna episod till ett meningsfullt ämnesinnehåll (semantisk förståelse) (Knapp \& Benton, 2006) Den första förutsättningen, om betydelsen av repetition, kan kopplas till sötvattensmärlan, som varit något av en nyckelorganism och som utgjort exempelorganismen i diskussioner om ekologiska processer och modeller som t.ex. näringspyramid eller näringskedja.. Arten och dess autekologi har blivit en form av meningsfull kunskap för att kunna resonera vidare om ekosystemet se Magntorn och Helldén (2006). Andra exempel på repetitioner är de håvningar och insamlande av djur och växter från ån som skedde vid flera tillfällen under våren och som de flesta elever refererar till. Den andra förutsättningen handlade om den upplevda relevansen av innehållet. Den tredje förutsättningen, om förstahandsupplevelser och praktiska övningar, fanns det stort utrymme för då undervisningen till stor del byggde på praktiska övningar i klassrummet och fältundersökningar. Men, som denna studie visat finns det stora skillnader mellan det de olika eleverna refererar till trots att de varit delaktiga i samtliga undervisningsmoment. Vad är det då som gör att dessa aktiviteter skapar minnesvärda episoder och varför refererar de bara till vissa saker men inte alls eller i liten utsträckning till andra tillfällen de varit med om vid undervisningen? Finns det några kvalitativt viktiga egen- 
skaper hos de mer minnesvärda episoderna? Den aspekt som inte betonas är de tillfällen som är svåra att planera för men som skapar just episoderna som förutsätts vara kopplingen mellan aktiviteten och den ämnesmässiga kunskapen. Det var till exempel. inte planerat att vissa slutna ekosystem skulle misslyckas och börja lukta väldigt illa. Detta blev dock en viktig episod som flera elever mindes. Det affektiva inslaget tycks vara starkare än det semantiska och inte sällan nämner eleverna bara dessa händelser utan att koppla det till ekologin på ett korrekt sätt. Att skapa episodiska minnen är bara en del av vägen till förståelse men det kan ge motivation och drivkraft at vilja förstå och lärarens förmåga att knyta an till episoderna på ett relevant sätt är centralt. I denna studie har inte elevernas förmåga att Läsa Naturen efter 18 månader utvärderats. Detta hade kunnat problematisera kopplingen mellan episodiska minnen och semantisk förståelse vilken inte är självklar. En annan aspekt är de episodiska minnen som eleverna nämner men som inte är direkt relaterade till förmågan att Läsa Naturen och därmed inte är en del av analysen.. Dessa har ofta att göra med känslor såsom att man minns hur kallt det var eller liknande. Dessa aspekter påverkar motivationen vilket har en direkt koppling till lärandet. Relevansen av innehållet kan ses utifrån en inre motivation som uppstår av elevens egen nyfikenhet eller vetgirighet inför mötet med det nya ekosystemet och dess organsimsvärld. I denna studie finns en entusiastisk lärare som genom sitt eget engagemang förmodligen också påverkat många elever till ett ökat intresse.

\section{KONSEKVENSER FÖR UNDERVISNINGEN}

Vad betyder då detta och vilka konsekvenser för undervisningen får det? Tunnicliffe och Ueckert (2007) hävdar att fältarbete är en ovanlig aktivitet som är "utrotningshotad" och att eleverna får för lite förstahands upplevelser utanför klassrummet och de hävdar att detta måste ändras. Detta är tyvärr en trend som också stämmer in på svenska förhållanden. Men som denna studie har visat handlar det inte bara om att förflytta en del av undervisningen från klassrummet ut i naturen eller flytta in naturen i form av organismer som eleverna hämtat in i klassrummet. Det handlar också om kvalitén på aktiviteterna. Det gäller att lärarna kan genomföra fältundervisning eller praktiska moment som genererar förstahandsupplevelser som är minnesvärda och att läraren tar nästa steg och kopplar dem till intellektuella färdigheter och förståelse. Det kan vara i form av direkta upplevelser i undervisningen som eleverna kan minnas under lång tid och som kan vara s.k. anchoring ideas (Novak, 1998) estetiska minnen eller upplevelser som bara enskilda elever har. Det är viktigt att planera och följa upp de praktiska momenten på ett klokt sätt. Det gäller att dessa moment ingår i en större helhet såsom det har varit i den lektionssekvens som beskrivits.

Fältarbete som skapar situationer som utmanar eleverna och som kräver att de aktivt försöker lösa uppgifter som de inte har svaren på skapar minnesvärda episoder hos många elever. Eleverna minns episoderna och kan länka dem till ekologiska sammanhang och resonemang men det är inte nödvändigtvis så att minnena är meningsfulla och direkt förknippade med en rationell förståelse av någon del av de naturvetenskapliga kunskapsmålen. Det är i detta sammanhang som läraren blir helt avgörande för resultatet. Episoderna behöver förankras i naturvetenskapen och detta måste ske av läraren som varit med under resan och som måste ta upp tråden och knyta an till de episoder som eleverna gemensamt varit med om. White och Gunstone (1992) skriver att elever minns saker som är ovanliga och spektakulära men undervisningen kan ju inte bygga på att skapa denna typ av situationer. Undervisning i naturvetenskap kan ju inte ha som mål att vara som en stor Kiviks marknad, späckad med spektakulära händelser och experiment. Denna studie har visat på hur elevinflytande, repetition av praktiska moment och fokus på få, kanske bara en organism och dess ekologi, kan leda långt och hålla intresset uppe. Elevernas ges inflytande och alla resultat är intressanta och kan diskuteras och förklaras. Episoder måste inte bara skapas under praktiskt arbete i klassrummet eller i fält men för att bli viktiga intellektuella redskap måste de kopplas till intellektuella färdigheter och teoretiska modeller. 


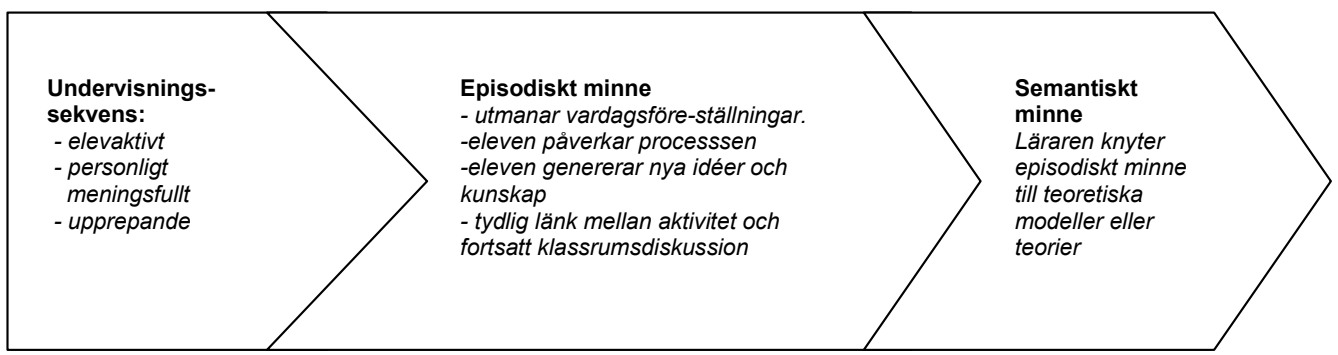

Figur 3. Figuren visar en modell för lärande med en övergång från episodiskt till semantiskt minne.

Detta ligger också i linje med resultaten i en stor kritisk utvärdering av No-undervisningen i Europa. Dessa resultat pekar tydligt på att undervisningen i naturvetenskap för elever under 14 år, skall betona engagemang, undersökande arbetssätt och "hands-on" aktiviteter och inte betona vikten av att lära sig förutbestämda begrepp (Osborne \& Dillon, 2008). Detta bör kompletteras med en betoning av att försöka skapa episoder i undervisningen som man kan återkomma till vid många tillfällen.

Inledningsvis i artikeln beskrevs hur elever som upplevt en dagslända kläckas fått episodiska minnen som var personliga men utgick från samma händelse. Detta är oundvikligt och beror på vad vi har med oss för tidigare erfarenheter men som pedagog kan man utnyttja denna typ av händelser för att knyta an till dem i undervisningen. Alla elever, oavsett förförståelse och erfarenhet minns själva händelsen och det kan ge en affektiv och motivationshöjande potential att anknyta till detta.

\section{REFERENSER}

Ausubel, D.P. (1968). Educational Psychology: A cognitive view. New York. Holt, Rinehart and Winston.

Biggs, J., \& Collis, K. (1982). Evaluating the quality of learning: The SOLO Taxonomy. New York: Academic Press.

Buckner, R.L., \& Barch, D. (1999) Images in Neuroscience - Episodic memory retrieval. American Journal of Psychiatry 156(9), 1311-1330.

Chawla, L. (1998). Significant life experiences revisited: A review of research on sources of environmental sensitivity. Journal of Environmental Education. 29(3), 11-21.

Clark, W. (1995) Narratology and the history of science. Studies in the History and Philosophy of Science, 24(1), 1-71.

Dere, E., Kart-Teke E., Huston J.P. \& De Souza Silva, M.A. (2006) The case for episodic memory in animals. Neuroscientific Biobehavioural Review. 30 (1), 1206-1224.

Duit, R., Treagust, D \& Mansfield. H.. (1996). Investigating students understanding as a prerequisite to improving teaching and learning in science and mathematics. In D.F. Treagust, R. Duit \& B.J. Fraser. (Eds) Improving Teaching and Learning in Science and Mathematics. 17-31. New York Teacher College Press.

Gagné, R. M., \& White, R. T. (1978). Memory structures and learning outcomes. Review of Educational Research, 48 (2), 187-222.

Helldén, G.F., \& Solomon. J. (2004). The persistence of personal and social themes in context: Long- and short-term studies of students' scientific ideas. Science Education 88 (6), 885-900.

Haglund, B. (2003) Stimulated Recall. Några anteckningar om en metod att generera data. Pedagogisk Forskning i Sverige 8 (3), 145-157.

Klein, P,D. (2006). The Challenges of Scientific Literacy. International Journal of Science Education 28 (2), 143-178. 
Knapp,D., \& Benton, G.M. (2006) Episodic and semantic memories of a residential environmental education program. Environmental Education Research 12 (2) 165-177.

Littledyke, M. (2008). Science education for environmental awareness: approaches to integrating cognitive and affective domains. Environmental Education Research 14 (1) 1-17.

Magntorn,O., \& Helldén. G. (2005). Student-Teachers' Ability to Read Nature: Reflections on their own learning in ecology. International Journal of Science Education 27 (10) 1229-1254.

Magntorn,O., \& Helldén,G. (2006) Reading Nature- experienced teachers' reflections on a teaching sequence in ecology: implications for future teacher training. NorDiNa-Nordic Studies in Science Education (5) 67-81.

Magntorn,O., \& Helldén,G. (2007) Reading nature from a 'bottom-up' perspective. Journal of Biological Education 41 (2) 68-75.

Novak,J.D.,(1998) Learning, creating and using knowledge. Mawhah, NJ: Lawrence Erlbaum Associates.

Orr, D.W. (1992). Ecological Literacy: education and the transition to a post modern world Albany State University of New York)

Osborne, J.F., \& Dillon, J. (2008). Science Education in Europe: Critical Reflections

Nuffield Foundation Report, 12 ..

Rickinson, M., Dillon, J., Teamey, K., Morris, K., Choi, M,Y., Sandres, D. and Benefield, P. (2004). A Review on Outdoor Learning. Field Studies Council, 8. National Foundation for Educational Research.

Thompson,T.L., \& Mintzes, J.J. (2002). Cognitive structure and affective domain: on knowing and feeling i biology. International Journal of Science Education. 24 (6) 645 - 660.

Tulving, E.(2002). Episodic memory: From mind to brain. Annual Review of Psychology. 53: 1-25.

Tunnicliffe, S., \& Ueckert, C, (2007) Teaching biology- the great dilemma. Journal of Biological Education, 41 (2) 51-57...

White,R., \& Gunstone R.(1992). Probing understanding. Falmer Press, London.

Watts, D., \& Alsop, S. 1997. A feeling for learning: Modelling affective learning in school science. The Curriculum Journal 8 351-365.

Wickman, P.-O. (2006). Aesthetic Experience in Science Education: Learning and Meaning-Making as Situated Talk and Action. Mahwah, New Jersey: Lawrence Erlbaum Associates. 